\title{
Значимость идентификаций в представлениях населения в контексте особенностей этноконтактной среды (на примере исследования в российских регионах)*
}

\author{
Н. С. ГАДЖИГАСАНОВА \\ ( ЯРОСЛАВСКИЙ ГОСУДАРСТВЕННЫЙ УНИВЕРСИТЕТ ИМ. П. Г. ДЕМИДОВА), \\ Н. Г. ХАЙРУЛЛИНА \\ (ТЮМЕНСКИЙ ГОСУДАРСТВЕННЫЙ НЕФТЕГАЗОВЫЙ УНИВЕРСИТЕТ)
}

Цель настоящей работы: выявление факторов, оказывающих воздействие на степень значимости идентификационных практик в представлениях населения, а также оценка влияния различных субъектов на межнациональные отношения. Представлены данные социологического исследования «Особенности формирования профиля идентификаций в условиях различной интенсивности этноконтактной среды», осуществленного авторами в 2014 г. в Ярославской и Вологодской областях, Республике Дагестан. Выборка - 1200 чел., опрос - анкетный. Опросный лист состоял из блоков: о соотношении гражданской, локальной, этнической и религиозной компонент в идентификационных представлениях населения; о частоте и характере контактов между представителями различных этнических групп; об интеграционных возможностях межэтнического взаимодействия российских народов; о воздействии социальных институтов на дестабилизацию межнациональных отношений. Результаты исследования показали, что в идентификационных представлениях опрошенных, проживающих на территориях с низким уровнем интенсивности этнических контактов (в Ярославской и Вологодской областях), гражданская самоидентификация обнаружена в ответах более $2 / 3$ респондентов. Среди жителей гетерогенного региона (в Республике Дагестан) выявлено одновременное сосуществование «на первой позиции» гражданской и этнической составляющих из соотношения два к одному $53,1 \%$ и 23,0\% ответов соответственно. Общая оценка межэтнического взаимодействия российских народов не однозначна. На фоне существования позитивной точки зрения о заинтересованности, основанной на доверии и симпатии этносов друг к другу (48,9\% респондентов), фиксируется наличие у 33,4\% признания недоверия, безразличия, антипатии. Более трети респондентов в проблеме дестабилизации межнациональных отношений признали наибольшим влияние националистических движений, СМИ, органов государственной власти в целом, отдельных чиновников в частности. Исследование показало, что в современных условиях идентификационная матрица жителей регионов одной страны как целостных социальных групп формируется из элементов, представляющих собой иерархический конгломерат различных социальных отождествлений. При этом гражданская, локальная, религиозная и этническая составляющие имеют различную степень значимости для ее обладателей в зависимости от особенностей этноконтактной среды, в которой они проживают.

Ключевые слова: идентичность; гражданская самоидентификация; этноконтактная среда; регионы России; межэтнические отношения; Ярославская область; Вологодская область; Республика Дагестан

\section{ВВЕАЕНИЕ}

\онятие идентичности за последние несколько десятилетий стало одной из наивого столетия в этом постоянно меняющемся мире большинство людей испытывают потребность в собственной принадлежности к сообществам, которые обеспечивают

* Работа выполнена при поддержке гранта Президента РФ № MK-1080.2014.6 (проект «Культура толерантности как фактор гармонизации межэтнических отношений»).

The article was prepared as part of the project "Culture of Tolerance as Factor of Harmonization of the Interethnic Relations" (supported by a grant of the President of the RF, No. MK-1080.2014.6). 
относительную уверенность, безопасность, а в некоторых случаях и удовлетворенность. Кроме этого, в рамках социально-гуманитарных наук подавляющее большинство исследователей разделяют точку зрения о том, что в нынешних реалиях социум - это поле непрерывно трансформирующихся идентичностей, проявляющееся в многообразных социальных практиках. В силу подобных тенденций представляется целесообразным, во-первых, дать историко-теоретическое обоснование понятия «идентичность» в социологической теории, во-вторых, операционализировать понятия «гражданская и этническая самоидентификация», в-третьих - представить результаты социологического исследования, воспроизводящие важности идентификационных категорий в оценках населения регионов в контексте особенностей этноконтактной среды.

\section{РАЗВИТИЕ ТЕОРЕТИЧЕСКИХ ПОАХОАОВ \\ К КОНЦЕПТУ «ИАЕНТИЧНОСТЬ»}

Согласно мнению ряда специалистов проблема идентичности - ключевая исследовательская проблема современной гуманитаристики (Михайлова, 2013; Санина, 2012; Рыжова, 2010; Российская идентичность в Москве ... , 2009). Так, например, 3. Бауман, размышляя об идентичности в глобализирующемся мире, отмечает: "..."идентичность" становится призмой, через которую рассматриваются, очениваются и изучаются многие важные черты современной жизни» (Бауман, 2002: 176). Само современное общество исследователь позиционирует как «индивидуализированное», в котором фиксируется разрушение ранее стабильных социальных связей, изолированность человека от окружающих, безразличие к другому, стремление к кратковременным межличностным отношениям, а также нерегулярность и непродолжительность социальных взаимодействий. 3. Бауман детерминирует подобные явления разочарованием индивида в возможности достижения собственных целей коллективными действиями (там же).

Между тем в контексте современных условий на фоне приоритетности инновационного развития российского общества необходимо использование механизмов, которые обеспечат консолидацию общероссийского гражданского самосознания (в соответствии со Стратегией государственной национальной политики Российской Федерации на период до 2025 года), но при условии сбалансированного соединения ее с этнической и региональной идентичностью. Наряду с этим как в научном сообществе, так и в политическом публичном пространстве присутствует точка зрения о том, что сегодня необходимо акцентировать внимание на выявлении региональных особенностей российской идентичности, в первую очередь применительно к районам с доминирующим по количеству русским населением, т. е. с учетом социального и культурного развития русских (Позитивный опыт регулирования ... , 2014; Аемидова, 2014 : Электронный ресурс).

В научной среде понятие «идентичность» получило распространение благодаря психологическим и антропологическим исследованиям Э. Эриксона в середине XX в., после чего термин стал достаточно популярен. В понятие идентичности Эриксон вкладывал следующие смыслы: осознание себя как индивида в данном телесном облике, окруженного определенными значимыми другими в своей культуре и обществе, т. е. осознание своей индивидуальности; чувство целостности собственной личности, непрерывности биографии; идентификация в разных сферах социального опыта и осознание собственной принадлежности к различным социальным группам; выделе- 
ние значимой характеристики личности для определенного исследования; способ размышлять о человеке в современном обществе (Эриксон, 2006).

Параллельно развивались и социологические теории идентичности, которые фокусировались на конструировании индивидуального «Я», или идентичности, посредством символических значений в межличностном взаимодействии. Родоначальником социологического понимания идентичности личности считают Аж. Г. Мида, который под идентичностью понимал способность человека воспринимать свое поведение как связное, единое целое, это равновесная система импульсивного, внутрипсихического $I$ и социального $M e$, что гарантирует успешную адаптацию человека. Следуя мысли Мида, идентичность есть результат постоянного диалога между внутрипсихическим $I$ и социальным $M е$, однако при этом идентичность формируется только при помощи других людей, отражая интерсубъективный космос социального мира. Аж. Г. Мид впервые показал непрерывность внутреннего состояния индивида, обусловленного органичной связью с социальным миром (Мид, 2009).

Концепция социальной идентичности, ставшая важной основой для многочисленных исследований по этнической идентичности во всем мире, разрабатывалась и в социальной психологии, практически на стыке с социологией. Большое влияние имеет теория, согласно которой социальная идентичность складывается из тех аспектов образа «Я», которые вытекают из восприятия индивидом себя как члена определенных социальных групп (Г. Тэджфел, Аж. Тернер). Один из основных тезисов данной концепции о ключевой роли позитивной социальной идентичности в межгрупповом взаимодействии, необходимой для повышения самооценки индивида и группы, сохраняет чрезвычайную актуальность для понимания сложных процессов формирования множественных идентичностей в современном мире. Как и в социологии, здесь индивид полностью помещен в социальный контекст, однако социальные психологи пользуются своим понятийным аппаратом при определении понятия «идентичность»: Я-образ, Я-концепция, самокатегоризация и др. Социологи говорят о том же, но с помощью других понятий, идентичность определяется через понятия «референтная группа», «групповое членство», «социальная роль», «социальный статус» и др. (Микляева, Румянцева, 2008).

Гражданская и этническая самоидентификации являются составными частями более общей социальной идентичности, анализ которых в современном научном дискурсе характеризуется многообразием и дискуссионностью подходов. Так, согласно точке зрения 3. Баумана в индивидуализированном обществе утрачиваются социальные и политические характеристики, потенциально формирующие «гражданина» и главное его качество - ответственность, так как, по мнению исследователя, коллективные «действия всегда были и будут в лучшем случае бесполезньми, а в худшем - вредньми с точки зрения благополучия и счастья отдельной личности» (Бауман, 2002: LXIV). Наряду с этим стоит иметь в виду, что только постмодернистские социогуманитарные теории принципиально пересмотрели идею статичной идентичности в условиях необратимых изменений и сосредоточили внимание на индивиде, чья идентичность условна, социально конструируема (Михайлова, 2013; Шадже, 2011; Киселев, Смирнова, 2001).

В российском научном дискурсе гражданская идентичность рассматривается как национально-гражданская идентичность (Санина, 2012; Российская идентичность в Москве ... , 2009), которую мы операционализировали как осознание индивидами и этносоциальными группами причастности к сообееству граждан России, основанное на когнитивной и эмоциональной привязанности к стране. 
ВЗАИМОСВЯЗЬ ИНТЕНСИВНОСТИ ЭТНОКОНТАКТНОЙ СРЕАЫ И ЗНАЧИМОСТИ ИАЕНТИФИКАЦИОННОЙ МАТРИЦЫ В ПРЕАСТАВАЕНИЯХ НАСЕАЕНИЯ РЕГИОНОВ

С целью выяснения степени распространенности и значимости общероссийской, локальной (региональной), религиозной, этнической идентичностей, рассмотрения особенностей сочетания и соотношения указанных идентичностей нами было проведено в 2014 г. социологическое исследование. Респондентами выступили жители регионов с разной интенсивностью этноконтактной среды (субъектами РФ с доминирующим русским населением, т. е. с низким уровнем контактов между разными этносами) - Ярославской и Вологодской областей. Также были охвачены опросом жители региона с высокой степенью этноконтактной среды - жители такого полиэтнического субъекта, как Республика Аагестан. Опрос взрослого населения осуществлялся с января по октябрь 2014 г., выборка - 1200 чел. Формирование выборки производилось с помощью квотного способа отбора, которая является статистически репрезентативной по следующим параметрам: этнической принадлежности, социально-демографических характеристик, территориального распределения респондентов по регионам.

Частными гипотезами нашего исследования выступили:

1. Гражданская и этническая идентичность занимают значимые позиции в идентификационных матрицах жителей регионов России.

2. Существуют значимые различия в идентификационных матрицах россиян, живущих в отличающихся по интенсивности этноконтактной среды субъектах: гражданская самоидентификация обнаруживает большую значимость в идентификационных представлениях населения, которое проживает в относительно гомогенной среде с низким уровнем интенсивности этнических контактов, этническая и религиозная в представлениях гетерогенного социума, в котором фиксируется высокая интенсивность контактов между представителями различных этнических групп.

Так, по данным нашего исследования, проведенного в указанных российских регионах, мы обнаружили, что гражданская самоидентификация на первой позиции обозначена в ответах более $2 / 3$ жителей монорегионов (Ярославской и Вологодской областей - 59,7\% и 63,4\% соответственно), в то время как среди жителей полиэтничного региона гражданином России «b первую очередь» себя ощущают только 53,1\% опрошенных, а почти четверть респондентов Аагестана заявили о значимости российского гражданства «в четвертую очередь»-23,0\%. На втором месте по значимости согласно мнению участников обследованных регионов чаще выступает локальная самоидентификация (1/3 всех ответов). В региональном разрезе распределение позиции "ошушаю себя жителем своего населенного пункта во вторую очередь" оказалось следующим: 33,7\% мнений в Ярославской области; в Аагестане и Вологодской области - 35,5\% и 37,0\% предпочтений соответственно. В отношении национальной принадлежности каждый третий респондент чаще всего актуализирует ее важность «B третью очередь» (35,8\% - в Вологодской области; 35,6\% - в Ярославской области; $32,0 \%$ - в Республике Аагестан). Наряду с этим религиозный компонент в идентификационной матрице представителей моноэтничных субъектов России чаще находится на четвертом месте $(40,5 \%$ и 46,0\% мнений респондентов - жителей Вологодской, Ярославской областей), тогда как треть дагестанских респондентов заявили, что чувствуют себя представителем своей религии «в первую очередь» - 33,8\%, т. е. допускают возможность сосуществования на первой позиции религиозной составляющей наряду с гражданской самоидентификацией. Отождествление с конструктом «ощущаю себя гражданином мира» признают более половины участников исследуе- 
мых регионов на пятой позиции (от 53,0\% жителей Вологодской области до 64,2\% дагестанцев).

Таким образом, мы зафиксировали, что сегодня гражданская самоидентификация более значима в идентификационных представлениях жителей, проживающих на территориях с низким уровнем интенсивности этнических контактов (для не менее $2 / 3$ респондентов из Ярославской и Вологодской областей); осознание локальной и этнической составляющих выражено респондентами в одинаковой степени на второй и третьей позициях соответственно без детерминированности от изначальных условий этноконтактной среды (от 33,4 до 37,9\%), а религиозная самоидентификация значима Аля жителей региона, в котором фиксируется высокая интенсивность контактов между представителями различных этнических групп (в нашем случае - Аагестана).

\section{ГОРАОСТЬ ЗА «БОАЬШУЮ» РОАИНУ}

Эмоциональную привязанность гражданской самоидентификации мы пытались зафиксировать посредством вопроса «Вызывает ли чувство гордости значительное культурное наследие страны?» Гордость за свою страну представляет собой важнейший индикатор отношения к гражданской принадлежности как к ценности. В этой связи становление гражданской идентичности закрепляется не только фактом осознания гражданской принадлежности, но и в большей степени тем отношением, которое к ней проявлено, и принятием данного факта как значимого в жизни человека.

Мы выяснили, что более $2 / 3$ респондентов заявили о наличии собственного чувства гордости в связи со значительным культурным наследием страны (80,3\%), в то время как каждый седьмой затруднился дать однозначный ответ $(13,3 \%)$, и только 6,4\% участников исследования не испытывают чувства национальной гордости. Чаще других положительно относятся к культурному наследию страны и ощущают чувство гордости за нее респонденты с высшим образованием (83,5\%), жители Вологодской области $(84,7 \%)$, респонденты старше 30 лет - 86,7\%, а также те, кто не сталкивался с отрицательным отношением к себе по этническому признаку $(80,9 \%)$. Согласно проведенному исследованию сталкивались с недоброжелательным отношением к себе из-за этнической принадлежности только 17,9\% респондентов; при этом доля респондентов, испытывающих неприязнь к представителям иных этнических групп из-за национальной принадлежности, составила $39,8 \%$.

Среди опрошенных, которые не смогли определиться с эмоциональной составляющей в содержании своей гражданской самоидентификации, чаще встречались более молодые люди (от 18 до 29 лет) - 13,5\% ответов, со средним специальным образованием $(16,1 \%)$, вне зависимости от региона проживания $(10,9,13,5$ и 13,8 в Ярославской, Вологодской областях и в Республике Аагестан соответственно). Вместе с тем наследие Родины не признает достойным чувства гордости чаще остальных каждый десятый опрошенный в возрасте от 18 до 22 лет (10,8\%); респонденты, получившие начальное и неполное среднее образование $(10,2 \%)$, а также проживающие в регионе с высокой интенсивностью этноконтактов: в Аагестане - 8,5\%, в моноэтничной Ярославской области - 7,4\%.

Рассматривая сущность этнической идентичности в рамках этносоциологического подхода, $\Lambda$. М. Аробижева к числу главных компонентов относит осознание принадлежности к своему народу (Российская идентичность в Москве ... , 2009: 11). При этом необходимо иметь в виду, что степень осознания принадлежности к собственному этносу может быть проинтерпретирована как устойчивая / двойная (неустойчивая) 
этническая самоидентификация либо обозначена как ее отсутствие (Сикевич, 1999). По данным нашего исследования обнаружилось: для подавляющего большинства респондентов характерна устойчивая этническая самоидентификация - в целом 80,1\% (в выборке Ярославской области - 84,3\%, Вологодской области - 83,1\%), но при этом в дагестанской выборке доля респондентов, однозначно положительно ответивших на вопрос «Ощущаете ли вы свою принадлежность к какой-либо национальности со своим языком, обычаями и традициями?», составила несколько меньше - 70,3\%. Это объясняется относительно высоким значением среди дагестанских участников иных вариантов ответа, свидетельствующих как о двойной (неустойчивой) этносамоидентификации $(17,1 \%)$, так и об отсутствии этнической самоидентификации $(12,6 \%)$. Аифференцированный анализ полученных данных по основным социально-демографическим группам опрашиваемых во всех регионах показывает: наиболее выражена устойчивая этническая самоидентификация у представителей молодежи в возрасте от 23 до 29 лет (82,8\%), а также среди тех, кто старше 50 лет (80,0\%). Аоля тех, кто характеризуется отсутствием этнической самоидентификации, достигла практически четверти респондентов в возрастной группе $18-29$ лет (22,8\%). Неустойчивой этнической самоидентификацией чаще других отличились участники опроса старше 30 лет $(24,5 \%)$.

Кроме этого, для выяснения степени открытости изучаемых региональных социумов участникам исследования нами был предложен вопрос «Насколько важно для вас жить среди людей своей национальности?» Ответы на него выявили высокую значимость проживания в гомогенной среде с низкой интенсивностью этнических контактов, Аля жителей Ярославского и Вологодского регионов $(71,1 \%$ и $74,9 \%$ соответственно), тогда как среди дагестанских респондентов о подобной избирательности заявила только треть респондентов (39,5\%).

В Стратегии государственной национальной политики Российской Федерации на период до 2025 года признается, что многообразие национального (этнического) состава и религиозной принадлежности населения России не только служит фактором укрепления российской государственности, но также и определяет состояние и позитивный вектор дальнейшего развития межнациональных отношений в Российской Федерации (Указ Президента ..., 2012: Электронный ресурс). В этой связи нами были проанализированы оценки респондентов относительно полиэтничного характера Российского государства. Поддерживают фразу «Россия - общий дом многих народов, оказывающих друг на друга свое влияние. Все народы России должны обладать равными правами, и никто не должен иметь никаких преимуществ» более $2 / 3$ всех опрошенных (70,5\%). По регионам эта средняя цифра сложилась из следующих: 50,6\% жителей Вологодской области, 68,8\% - Ярославской области, 92,6\% - Аагестана. С фразой «Россия - многонациональная страна, но русские, составляя большинство, должны иметь больше прав, ибо на них лежит основная ответственность за судьбу страны в целом» согласны в целом 22,7\% опрошенных: в числе «мягких националистов» почти треть респондентов из регионов с низкой интенсивностью этнических контактов (24,8\% в Ярославской, 35,5\% - в Вологодской области), только 6,1\% сторонников в Аагестане, а также более трети людей со средним специальным образованием (34,0\%).

Наряду с этим идея «Россия должна быть государством русских людей» находит подАержку у 6,8\% из числа всех опрошенных: 1,2\% мнений в Аагестане, а также $6,3 \%$ и $13,9 \%$ ответов в Ярославской и Вологодской областях соответственно, а также у 9,7\% опрошенных, указавших на наличие только общего среднего образования. 
Присутствие радикальных русских националистов отмечается и в ряде других всероссийских исследований (Студенчество в многонациональных мегаполисах ..., 2008; Российская идентичность ..., 2007).

\section{О ПОТЕНЦИААЕ МЕЖЭТНИЧЕСКИХ ОТНОШЕНИЙ}

С целью оценить возможности интеграционной составляющей в межэтническом взаимодействии российских народов в анкету был включен вопрос «С вашей точки зрения, в отношениях между народами России преобладают...» - с рядом вариантов ответов. Ответы представили следующую картину: более трети участников массового опроса поддержали мнение, что на современном этапе в российском социуме присутствует заинтересованность $(54,2 \%)$, основанная на доверии $(47,7 \%)$ и симпатии этносов друг к другу $(45,0 \%)$. Наряду с этим более трети респондентов охарактеризовали межэтнические взаимоотношения российских этносов категорией «недоверие» $(40,5 \%)$, в то время как на присутствие признаков безразличия, антипатии в отношениях народов указали $29,5 \%: 30,5 \%$ опрошенных соответственно (табл. 1 ).

РАСПРЕАЕАЕНИЕ ОТВЕТОВ НА ВОПРОС «С ВАШЕЙ ТОЧКИ ЗРЕНИЯ,

Таблица 1

В ОТНОШЕНИЯХ МЕЖАУ НАРОААМИ РОССИИ ПРЕОБААААЮТ...»

(N=1200, ЯНВАРЬ — ОКТЯБРЬ 2014 г., В \% ОТ ЧИСАА ОТВЕТИВШИХ)

Table 1

DISTRIBUTION OF ANSWERS TO THE QUESTION “IN YOUR VIEW,

WHAT IS THE PREVALENT FACTOR IN INTERETHNIC RELATIONS WITHIN RUSSIA?”

( $\mathrm{N}=1200$, JANUARY — OCTOBER 2014, \% OF RESPONDENTS).

\begin{tabular}{|c|c|c|c|c|c|c|}
\hline & \multicolumn{6}{|c|}{ В отношениях между народами России преобладают... } \\
\hline & 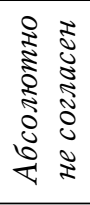 & 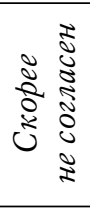 & 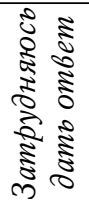 & 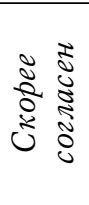 & 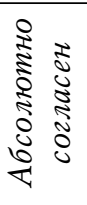 & Итого \\
\hline Аоверие & 11,2 & 17,2 & 23,9 & 31,3 & 16,4 & 100 \\
\hline Недоверие & 12,4 & 18,7 & 28,4 & 26,7 & 13,8 & 100 \\
\hline Симпатия & 10,0 & 14,5 & 30,5 & 28,8 & 16,1 & 100 \\
\hline Антипатия & 13,5 & 19,6 & 36,6 & 19,8 & 10,4 & 100 \\
\hline Заинтересованность & 5,5 & 12,5 & 27,8 & 33,2 & 21,0 & 100 \\
\hline Безразличие & 16,6 & 17,9 & 36,0 & 17,9 & 11,6 & 100 \\
\hline
\end{tabular}

При анализе данного вопроса по переменной «регион проживания респондента», мы обнаружили: более $57,5 \%$ жителей Аагестана чаще высказывались о том, что во взаимоотношениях российских народов преобладают заинтересованность, тогда как наименее популярным среди дагестанцев оказался вариант «В отношениях между народами присутствует антипатия» - 21,8\% ответов. В ответах респондентов Вологод- 
ской области одновременно пересекались такие характеристики, как заинтересованность $(51,6 \%)$, недоверие $(45,5 \%)$ и антипатия $(37,8 \%)$. Вместе с тем ярославцы оценили отношения российских народов как основанные на взаимном интересе $(52,9 \%)$, симпатии $(39,7 \%)$, а также амбивалентности по шкале «доверие / недоверие» $(44,9 \%$ сторонников доверия против 43,0\% недоверяющих). Подобные оценки в распределении ответов участников исследования по каждой позиции свидетельствуют об отсутствии однозначности, противоречивости в субъективных оценках характера отношений между российскими народами, что в определенной степени вытекает из самой сложной природы межэтнических взаимодействий. Аналогичные выводы получены Ч. К. Аамажаа, Н. Г. Хайруллиной в ходе исследований, проведенных в других российских регионах (Мамажаа, Хайруллина, 2015).

Между тем, согласно данным информационно-аналитического резюме по итогам общенационального исследования «Российское общество в контексте новых реалий» (2015, N = 4000 (от 18 лет и старше), проживающие во всех территориально-экономических районах РФ и во всех типах поселений), 43,0\% респондентов, оценивая изменения в сфере межнациональных отношений за период с 2004 по 2014 г., отметили негативную динамику, так как высказали мнение, что межнациональные отношения стали хуже. Аругая треть соотечественников охарактеризовала межнациональную сферу как статичную, не имеющую каких-либо изменений на протяжении последнего десятилетия (39,0\%). Позитивные тренды в атмосфере межэтнических отношений были высказаны только 18,0\% опрошенных (Информационно-аналитическое резюме по итогам ..., 2015: Электронный ресурс).

Однако стоит отметить, что согласно более раннему исследованию Е. А. Кублицкой, в котором автор предприняла попытку выделить различные типы регионов в зависимости от состояния в них межнациональных отношений, Ярославская и Вологодская области относятся к регионам со средней степенью национальной напряженности (36\% и 49\% соответственно) (Кублицкая: Электронный ресурс). Между тем наши исследования не подтверждают подобные данные. Аело в том, что в рамках нашего проекта мы также обратились к жителям обследуемых трех регионов с открытым вопросом «Очените, пожалуйста, начиональные отношения $b$ населенном пункте, где вы проживаете..." Обнаружилось, что более половины респондентов в регионах с низкой интенсивностью этнических контактов оценивает атмосферу национальных отношений как «спокойную / нормальную / уравновешенную / стабильную» (60,6\% мнений ярославцев и $64,1 \%$ опрошенных в Вологодской области), тогда как у респондентов с высокой интенсивностью этнических контактов (Аагестана) подобная оценка встретилась только в 20,9\% ответов. При этом отличительной особенностью оценок участников многонационального региона выступает весомая доля позитивных характеристик состояния межнациональной ситуации - выявлено 63,4\% мнений о «доброжелательных / хороших / положительных / добрососедских взаимоотношениях между этническими группами / живуших в полном мире» по сравнению с 15,4\% : $17,2 \%$ аналогичных ответов в Вологодской и Ярославской выборках соответственно. Наряду с этим если чаще заявляли о напряженном характере межэтнической ситуации жители Ярославского региона, а также опрошенные в возрастной группе от 18 до 22 лет (7,6\% и 7,9\% оценок соответственно), то респонденты Вологодского региона и Аагестана наравне с напряженностью (3,6\% : 3,5\%) высказываются о неблагоприятности национальных отношений (2,6\% и 2,9\% соответственно). Твердо уверен, что взаимоотношения в межнациональной сфере нуждаются в корректировке, практически 
каждый десятый житель обоих регионов с невысоким уровнем этнических контактов $(9,6 \%$ ответов в Ярославской и $10,3 \%$ - в Вологодской области), а также представители старших возрастных групп (от 8,7\% в группе респондентов старше 50 лет до $12,0 \%$ опрошенных в возрасте от 23 до 30 лет). В целом столь неоднозначные социальные процессы в контексте гармонизации сферы межэтнических отношений могут стать направлениями и ориентирами для дальнейшей деятельности как научной общественности, так и ответственных специалистов, направленной на реализацию национальной политики с привлечением потенциала общественных организаций при возрастании активности и заинтересованности самих граждан.

\section{ОЦЕНКА ВАИЯНИЯ РАЗАИЧНЫХ СУБЪЕКТОВ \\ НА МЕЖНАЦИОНААБНЫЕ ОТНОШЕНИЯ}

В Стратегии государственной национальной политики Российской Федерации на период до 2025 года (в разделе «Механизмы реализации государственной национальной политики РФ») указывается, что эффективность реализации государственной национальной политики России обеспечивается непрерывной и согласованной деятельностью государственных органов и органов местного самоуправления, институтов гражданского общества (Указ Президента ... , 2012: Электронный ресурс). При этом законодательство нашей страны в сфере регулирования национальных отношений характеризуется существенными нововведениями (Гаджигасанова, Хайруллина, 2015).

Поэтому в данной работе нам представляется интересным анализ общественного мнения о возможности влияния на ухудшение межнациональных отношений в российском обществе таких субъектов, как органы государственной власти, чиновники, отдельные граждане, националистические движения, диаспоры, землячества, СМИ, политические партии, религиозные организации (табл. 2).

Согласно полученным данным наибольший потенциал и возможности дестабилизации атмосферы межнациональных отношений признаются за националистическими движениями (46,6\% респондентов); СМИ (38,2\%); органами государственной власти (в том числе чиновниками) $(34,1 \%)$. Чаще высказывались о значимой роли националистических движений респонденты двух возрастных групп: 1$)$ от 18 до 22 лет (50,9\%); 2) от 30 до 49 лет (47,8\%). При этом на активность СМИ более других указывают респонденты Вологодского региона $(41,5 \%)$ и жители Аагестана $(39,2 \%)$. Наряду с этим наибольшая доля негативных оценок в отношение госорганов принадлежит респондентам, проживающим в Аагестане (41,7\%), участникам возрастной группы от 50 лет и старше $(38,5 \%)$, а также опрошенным со средним специальным либо высшим образованием ( $36,3 \%$ и $34,1 \%$ соответственно). Наименьшее воздействие согласно мнению опрошенных может оказать деятельность диаспор (48,8\%), религиозных организаций $(48,8 \%)$ и политических партий $(45,8 \%)$. При этом чаще признают высокую степень влияния в анализируемом контексте работы политических партий респонденты в возрасте от 50 лет и старше $(31,5 \%)$.

Аетальный анализ возможностей печатных СМИ в сфере гармонизации межэтнических взаимодействий, осуществленный авторами ранее, позволил сформулировать вывод о том, что на современном этапе потенциал печатных СМИ полностью не реализован (Гаджигасанова, Аудина, Хайруллина, 2015: Электронный ресурс).

При этом стоит учитывать, что анализ представлений жителей регионов о возможностях влияния различных институциональных структур (госорганы, националистические движения, диаспоры, СМИ и др.) на дестабилизацию атмосферы межнацио- 
Таблица 2

РАСПРЕАЕАЕНИЕ ОТВЕТОВ НА ВОПРОС «ОЦЕНИТЕ, ПОЖААУЙСТА, СТЕПЕНЬ ВАИЯНИЯ НА УХУАШЕНИЕ МЕЖНАЦИОНААЬНЫХ ОТНОШЕНИЙ В СОВРЕМЕННОМ РОССИЙСКОМ ОБЩЕСТВЕ САЕАУЮЩИХ СУБЪЕКТОВ...», В \% ОТ ЧИС АА ОТВЕТИВШИХ

Table 2 DISTRIBUTION OF ANSWERS TO THE QUESTION “PLEASE ESTIMATE HOW THE FOLLOWING SUBJECTS CONTRIBUTE TO THE DETERIORATION OF INTERETHNIC RELATIONS IN CONTEMPORARY RUSSIAN SOCIETY", \% OF RESPONDENTS

\begin{tabular}{|c|c|c|c|c|}
\hline & $\begin{array}{c}\text { Не оказывают/ } \\
\text { скорее не влияют } \\
\text { на сферу } \\
\text { межначиональных } \\
\text { отночений }\end{array}$ & \begin{tabular}{|c|} 
Менее других \\
субъектов \\
вовлекаются \\
в сферу \\
регулирования \\
межначиональньх \\
отношении
\end{tabular} & \begin{tabular}{|c|} 
Такал же роль, \\
как и у других \\
участников \\
межначиональньх \\
взаимодействий
\end{tabular} & $\begin{array}{c}\text { Принадлежит } \\
\text { главнал роль } \\
\text { в регулировании } \\
\text { межначиональных } \\
\text { отночений }\end{array}$ \\
\hline $\begin{array}{c}\text { Государственные } \\
\text { органы власти, } \\
\text { чиновники }\end{array}$ & 44,4 & 11,7 & 9,9 & 34,1 \\
\hline $\begin{array}{l}\text { Отдельные } \\
\text { граждане }\end{array}$ & 41,7 & 12,1 & 14,6 & 31,5 \\
\hline $\begin{array}{c}\text { Националистиче- } \\
\text { ские движения }\end{array}$ & 27,5 & 9,9 & 15,9 & 46,6 \\
\hline $\begin{array}{l}\text { Аиаспоры, } \\
\text { землячества }\end{array}$ & 48,8 & 15,1 & 11,1 & 25,1 \\
\hline СМИ & 32,3 & 14,6 & 14,9 & 38,2 \\
\hline $\begin{array}{l}\text { Политические } \\
\text { партии }\end{array}$ & 45,8 & 17,4 & 12,0 & 24,8 \\
\hline $\begin{array}{l}\text { Религиозные } \\
\text { организации }\end{array}$ & 48,8 & 11,3 & 10,5 & 29,5 \\
\hline
\end{tabular}

нальных отношений выявил: если вклад СМИ участники исследования в данном аспекте оценили достаточно высоко (на второй позиции среди всех оцениваемых субъектов) наряду с работой националистических движений, то государственные органы власти и религиозные организации не получили однозначных оценок респондентов об их роли в области регулирования отношений в национальной сфере. Аело в том, что в числе опрошенных наряду с третью респондентов, признающих за госорганами одну из ведущих ролей в дестабилизации гармонии в межнациональной сфере, другая треть опрошенных отрицает какое-либо участие госорганов в регулировании межэтнических взаимодействий $(44,4 \%)$. Что касается религиозных организаций, то и здесь наравне с 48,8\% мнений об отсутствии их влияния на отношения между представителями разных народов почти треть участников высказывают мнение об их главной роли в ухудшении стабильности межнациональной атмосферы $(29,5 \%)$, причем чаще других об этом заявляют жители Аагестана (42,0\%). Активность отдельных граждан в изучаемом нами контексте чаще других высоко оценили дагестанские респонденты (40,5\%), а также опрошенные возрастной группы от 30 до 49 лет (36,7\%). Отметим, что потенциал толерантной социализации личности авторами ранее исследовался (Хайруллина, Гаджигасанова, 2015: Электронный ресурс). 


\section{ЗАКАЮЧЕНИЕ}

Общими положениями, разделяемыми большинством исследователей проблемы идентичности, мы обозначили следующие: источник формирования идентичности - социальная и культурная среда, межличностное взаимодействие; идентичность предстает как аспект самосознания, осознанности; она рассматривается как интегрированное переживание жизненной ситуации; идентичность часто выступает как воображаемая целостность; идентичность превращается в современном обществе в «рефлексивный проект»; она характеризуется как незавершенный проект в силу культурного плюрализма и сложности современного мира, опосредованного виртуальной коммуникацией.

Мы выяснили, что в современных условиях идентификационная матрица жителей регионов одной страны как целостных социальных групп формируется из элементов, представляющих собой иерархический конгломерат различных социальных отождествлений. При этом гражданская, локальная, религиозная и этническая составляющие имеют различную степень значимости для ее обладателей в зависимости от особенностей этноконтактной среды, в которой они проживают. Анализ эмоциональной составляющей в структуре гражданской идентификации выявил значительную долю респондентов, не испытывающих чувства гордости за свою страну. Аанное обстоятельство обусловливает важность расширения спектра мероприятий, направленных на популяризацию культурного наследия страны, которые будут реализовываться средствами и силами как первичных, так и вторичных агентов социализации (семьи, образовательных учреждений, национально-культурных организаций/ диаспор, СМИ, религиозных объединений, при содействии региональных правительств и муниципальных органов власти) с целью снижения числа жителей, не ощущающих чувства национальной гордости.

В ходе этносоциологического исследования выявлено, что в представлениях разных групп населения присутствует стабильная и в то же время тревожная оценка о деструктивной роли проанализированных нами субъектов в регулировании вопросов, связанных с созданием условий для укрепления государственного единства, формирования общероссийского гражданского самосознания, развития межнационального (межэтнического) и межрелигиозного диалога. Наибольшее влияние на дестабилизаиию атмосферы межначиональных отношений, по мнению жителей регионов, могут оказыьать начионалистические движения, СМИ, органы государственной власти, тогда как наименьшее признано за деятельностью диаспор, религиозньх организаиий, политических партий. Все это происходит на фоне принятия и действия на государственном уровне Стратегии государственной национальной политики Российской Федерации на период до 2025 года (от 19 декабря 2012 г.), ряда других нормативных документов совместно с региональными программами, направленными на укрепление гражданского единства и гармонизацию межнациональных отношений. Подобные явления могут свидетельствовать о низкой информированности населения, малой эффективности реализации указанных программ.

Мы предлагаем всем участникам и субъектам межнациональных отношений активизировать усилия по содействию и освещению процессов этнокультурного развития народов и регионов; на конструировании толерантных образов этнических групп, регионов страны; на распространении интеграционных ценностей и символов в регионах и в стране в целом; на формах и методах идеологического формирования общегражданской идентичности, созидательного, мирного взаимодействия этнических групп. 
В целях успешной реализации и популяризации мероприятий в сфере укрепления единства российской нации и этнокультурного развития народов считаем целесообразным учитывать, что необходимо не только обеспечить регулярность, систематичность, непрерывность информационно-пропагандистского процесса, но и соблюдать преемственность воздействия пропаганды (в работе органов государственной власти, СМИ, национально-культурных объединений, религиозных организаций и др.). Наряду с этим к популяризации межнационального сотрудничества, к формированию конструктивного диалога, укреплению гражданского единства среди различных категорий и групп населения необходимо подходить дифференцированно, с учетом их социальнодемографических особенностей и характера опыта межэтнического взаимодействия.

\section{СПИСОК АИТЕРАТУРЫ}

Бауман, 3. (2002) Индивидуализированное общество / пер. с англ. под ред. В. А. Иноземцева. М. : Аогос. 390 c.

Гаджигасанова, Н. С., Аудина, И. М., Хайруллина, Н. Г. (2015) Специфика социальной дистанции и противоречия межэтнического взаимодействия этносоциальных групп [Электронный pecypc] // Современные проблемы науки и образования. № 2. Ч. 2. URL: http://science-education.ru/129-21962 [архивировано в WebCite] (дата обращения: 10.09.2015).

Гаджигасанова, Н. С., Хайруллина, Н. Г. (2015) Особенности проявления этнической толерантности в малых социальных группах в моно- и полиэтничном регионах России // Знание. Понимание. Умение. № 3. С. 53-71. DOI: 10.17805/zpu.2015.3.5

Аемидова, М. (2014) В Ярославле обсудят региональный аспект российской идентичности [Электронный ресурс] // Ярославский регион. 23 октября. URL: http://yarreg.ru/articles/20141023122504 [архивировано в WebCite] (дата обращения: 30.08.2015).

Информационно-аналитическое резюме по итогам общенационального исследования «Российское общество в контексте новых реалий» (тезисы о главном) (2015) [Электронный ресурс]// Институт социологии PAH. URL: http://isras.ru/files/File/publ/resume_isras_28.01.2015.pdf [apхивировано в WebCite] (дата обращения: 3.05.2015).

Киселев, И. Ю., Смирнова, А. Г. (2001) Формирование идентичности в российской провинции. М. ; Ярославль : АИА-пресс. 152 с.

Кублицкая, Е. А. Межнациональные отношения и толерантность [Электронный ресурс]// Институт социально-политических исследований PAH. URL: http://isprras.ru/pics/File/Kublickaya.pdf [архивировано в WebCite] (дата обращения: 12.05.2015).

Аамажаа, Ч. К., Хайруллина, Н. Г. (2015) Архаизация и неотрадиционализм в регионах Уральского федерального округа // Знание. Понимание. Умение. № 1. С. 29-38. DOI: 10.17805/ zpu.2015.1.3

Мид, Аж. Г. (2009) Избранное : сб. переводов / сост. и пер. В. Г. Николаев ; отв. ред. А. В. Ефременко. М. : ИНИОН РАН. 290 с.

Микляева, А. В., Румянцева, П. В. (2008) Социальная идентичность дичности: содержание, структура, механизмы формирования. СПб. : ИзА-во РГПУ им. А. И. Герцена. 118 с.

Михайлова, О. Ю. (2013) Концепт идентичности: прыжок через парадигмальный разрыв // История и современность. № 2 (18). С. 200-213.

Позитивный опыт регулирования этносоциальных и этнокультурных процессов в регионах Российской Федерации (2014): Материалы Всероссийской научно-практической конференции, Казань, 25-27 сентября 2014 г. / отв. ред. Г. Ф. Габдрахманова. Казань : Институт истории им. Ш. Марджани АН РТ. 508 с.

Российская идентичность в Москве и регионах (2009) / отв. ред. А. М. Аробижева. М. : Институт социологии РАН ; МАКС Пресс. 268 с.

Российская идентичность в социологическом измерении (2007): Аналитический доклад. Подготовлен в сотрудничестве с Представительством Фонда имени Фридриха Эберта в Российской Федерации. М. : Институт социологии РАН. 140 с. 
Рыжова, С. В. (2010) Идентичность и интеграционные установки в региональном контексте: исследование в Москве и Сочи // Вестник Института социологии. № 1. С. 443-462.

Санина, А. Г. (2012) Формирование российской идентичности: гражданско-государственный подход // Социологические исследования. № 12. С. 57-65.

Сикевич, 3. В. (1999) Социология и психология национальных отношений. СПб. : ИзА-во Михайлова В. А. 203 с.

Студенчество в многонациональных мегаполисах и крупных городах России: этническое самосознание и межэтнические отношения (2008) : сб. материалов по результатам социологического исследования / А. Н. Покида, Н. В. Зыбуновская, А. Ф. Аашдамиров, С. А. Пистрякова, С. А. Семедов, А. Ю. Соклаков, Ж. А. Шишова ; под ред. А. В. Журавского. М. : ИзА-во Российской академии гос. службы при Президенте РФ. 156 с.

Указ Президента Российской Федерации от 19.12.2012 г. № 1666 «О Стратегии государственной национальной политики Российской Федерации на период до 2025 года» (2012) [Электронный ресурс]// Президент России. 19 декабря. URL: http://kremlin.ru/acts/bank/36512 [apхивировано в WebCite] (дата обращения: 12.09.2015).

Хайруллина, Н. Г., Гаджигасанова, Н. С. (2015) Проявление этнической толерантности в малых социальных группах [Электронный ресурс] // Современные проблемы науки и образования. № 2 (58). URL: http://science-education.ru/122-21309 [архивировано в WebCite] (дата обращения: 12.09.2015).

Шадже, А. Ю. (2011) Идентичность в контексте постнеклассической науки // Идентичность как предмет политического анализа : сб. статей по итогам Всероссийской научно-теоретической конференции (ИМЭМО РАН, 21-22 октября 2010 г.) / отв. ред. И. С. Семененко, А. А. Фадеева. М. : ИМЭМО РАН. 299 с. С. 42-46.

Эриксон, Э. Х. (2006) Идентичность: юность и кризис / общ. ред. А. В. Толстых ; пер. с англ. М. : Флинта ; МПСИ ; Прогресс. 352 с.

Аата поступления: 12.09.2015 г.

THE IMPORTANCE OF IDENTIFICATIONS AS SEEN BY THE POPULATION IN THE CONTEXT OF ETHNOCONTACT ENVIRONMENT

\author{
(THE CASE OF RUSSIA'S REGIONS) \\ N. S. GADZHIGASANOVA \\ (P. G. Demidov Yaroslavl State UnIVERSITY), \\ N. G. KHAIRULLINA \\ (TYUMEN STATE OIL AND GAS UNIVERSITY)
}

Modern societies are construed as a field of continuously transformed identities, manifesting themselves through various social practices. Our article aims to identify the factors which have an impact on the importance of identification practices as viewed by the population. Also provided is an assessment of how various subjects influence interethnic relations.

The article presents the data of a sociological study titled "Features of Formation of a Profile of Identifications in the Conditions of Various Intensity of the Ethnocontact Environment" which was carried out by the authors in 2014 in the Yaroslavl and Vologda Oblasts and in the Republic of Dagestan. The study covered 1200 people, who had to fill in a questionnaire that was supposed to survey the notions of a balance between the civic, local, ethnic and religious components of identification. Other question blocks provided their opinions on the frequency and nature of contacts between representatives of various ethnic groups; on integration capability of interethnic communication in Russia; and on the impact social institutes may have on the destabilization of interethnic relations.

The outcomes of our study clearly demonstrate that identification practices of the respondents residing in territories with a low level of ethnic contact intensity (Yaroslavl and Vologda Oblasts) frequently feature civic self-identification (over $2 / 3$ of all respondents). Among the population of an ethnically heterogeneous region (in our case, the Republic of Dagestan), the civic and ethnic components 
are featured in a ratio of $2: 1-53,1 \%$ and $23,0 \%$ of answers respectively. An overall assessment of interethnic communication in Russia is not unambiguous, according to our respondents. $48,9 \%$ of them supported an assertive view of the mutual interest based on trust and sympathy that exist between ethnicities, while $33,4 \%$ of survey participants admitted the existence of interethnic mistrust, indifference or even antipathy. Speaking of the destabilizing influences on interethnic relations, over a third of the respondents mentioned nationalist movements, mass media, the authorities as a whole, as well as some public officials in particular.

Our research has shown that in current conditions the identification matrix of the residents of regions within one country as parts of a single social group comprises a hierarchical conglomerate of various social identifications. At the same time, various degrees of importance can be assigned to civic, local, religious and ethnic components depending on the particular ethnocontact environment they live in.

Keywords: identity; civic self-identification; ethnocontact environment; Russia's regions; interethnic relations; Yaroslavl Oblast; Vologda Oblast; Republic of Dagestan

\section{REFERENCES}

Bauman, Z. (2002) Individualizirovannoe obshchestvo [Individualized society]/ transl. from English ed. by V. L. Inozemtsev. Moscow, Logos Publ. 390 p. (In Russ.).

Gadzhigasanova, N. S., Dudina, I. M. and Khairullina, N. G. (2015) Spetsifika sotsial'noi distantsii i protivorechiia mezhetnicheskogo vzaimodeistviia etnosotsial'nykh grupp [Specificity of social distance and contradictions in interethnic communication between ethnosocial groups]. Sovremennye problemy nauki i obrazovaniia, no. 2, pt. 2. [online] Available at: http://science-education.ru/ 129-21962 [archived in WebCite] (accessed 10.09.2015). (In Russ.).

Gadzhigasanova, N. S. and Khairullina, N. G. (2015) Osobennosti proiavleniia etnicheskoi tolerantnosti v malykh sotsial'nykh gruppakh $\mathrm{v}$ mono- i polietnichnom regionakh Rossii [Manifestations of ethnic tolerance in small social groups in Russia's mono- and polyethnic regions]. Znanie. Ponimanie. Umenie, no. 3, pp. 53-71. DOI: 10.17805/zpu.2015.3.5 (In Russ.).

Demidova, M. (2014) V Iaroslavle obsudiat regional'nyi aspekt rossiiskoi identichnosti [Policymakers to discuss the regional aspect of the Russian identity in Yaroslavl]. Iaroslavskii region, October 23. [online] Available at: http://yarreg.ru/articles/20141023122504 [archived in WebCite] (accessed 30.08.2015). (In Russ.).

Informatsionno-analiticheskoe reziume po itogam obshchenatsional'nogo issledovaniia «Rossiiskoe obshchestvo v kontekste novykh realii» (tezisy o glavnom) [Information and analytical summary regarding the results of the nationwide study "The Russian Society in the Context of New Realities" (main points)]. (2015) Institut sotsiologii RAN [Institute of Sociology, RAS] [online] Available at: http://isras.ru/files/File/publ/resume_isras_28.01.2015.pdf [archived in WebCite] (accessed 3.05.2015). (In Russ.).

Kiselev, I. Yu. and Smirnova, A. G. (2001) Formirovanie identichnosti v rossiiskoi provintsii [Identity building in provincial Russia]. Moscow ; Yaroslavl, DIA-press. 152 p. (In Russ.).

Kublitskaia, E. A. Mezhnatsional'nye otnosheniia i tolerantnost' [Interethnic relations and tolerance]. Institut sotsial' no-politicheskikb issledovanii RAN [The Institute of Socio-Political Research, RAS] [online] Available at: http://isprras.ru/pics/File/Kublickaya.pdf [archived in WebCite] (access date 12.05.2015). (In Russ.).

Lamazhaa, Ch. K. and Khairullina, N. G. (2015) Arkhaizatsiia i neotraditsionalizm v regionakh Ural'skogo federal'nogo okruga [Archaization and neo-traditionalism in the regions of the Ural Federal District]. Znanie. Ponimanie. Umenie, no. 1, pp. 29-38. DOI: 10.17805/zpu.2015.1.3 (In Russ.).

Mead, G. H. (2009) Izbrannoe [Selected works] / collect. and transl. by V. G. Nikolaev; ed. by D. V. Efremenko. Moscow, Institute of Scientific Information on Social Sciences Publ. 290 p. (In Russ.).

Mikliaeva, A. V. and Rumiantseva, P. V. (2008) Sotsial' naia identichnost' lichnosti: soderzbanie, struktura, mekbanizmy formirovaniia [Social identity of the person: Contents, structure, mechanisms of building]. St. Petersburg, The Herzen State Pedagogical University of Russia Publ. 118 p. (In Russ.). 
Mikhailova, O. Yu. (2013) Kontsept identichnosti: pryzhok cherez paradigmal'nyi razryv [The concept of identity: A leap across the paradigmal gap]. Istoriia $i$ sovremennost', no. 2 (18), pp. 200-213. (In Russ.).

Pozitivnyi opyt regulirovaniia etnosotsial'nykh $i$ etnokul'turnykb protsessov $v$ regionakb Rossiiskoi Federatsii [Positive experience of regulating ethnosocial and ethnocultural processes in the regions of the Russian Federation] (2014) : Proceedings of all-Russian conference, Kazan, September 25-27, 2014 / ed. by G. F. Gabdrakhmanova. Kazan, Publ. House of Sh. Marjani Institute of History, Tatarstan Academy of Sciences. 508 p. (In Russ.).

Rossiiskaia identichnost' $v$ Moskve i regionakb [The Russian identity in Moscow and the regions] (2009) / ed. by. L. M. Drobizheva. Moscow, Publ. House of the Institute of Sociology, RAS ; MAKS Press. 268 p. (In Russ.).

Rossiiskaia identichnost' $v$ sotsiologicheskom izmerenii [The Russian identity in its sociological dimension] (2007) : An analytical report prepared in collaboration with the Russian Office of the Friedrich Ebert Foundation. Moscow, Publ. House of the Institute of Sociology, RAS. 140 p. (In Russ.).

Ryzhova, S. V. (2010) Identichnost' i integratsionnye ustanovki v regional'nom kontekste: issledovanie v Moskve i Sochi [Identity and integration values in a regional context: A study of Moscow and Sochi]. Vestnik Instituta sotsiologii, no. 1, pp. 443-462. (In Russ.).

Sanina, A. G. (2012) Formirovanie rossiiskoi identichnosti: grazhdansko-gosudarstvennyi podkhod [The rise of the Russian identity: Civic and state-centered approach]. Sotsiologicheskie issledovaniia, no. 12, pp. 57-65. (In Russ.).

Sikevich, Z. V. (1999) Sotsiologiia i psikbologiia natsional'nykb otnoshenii [Sociology and psychology of interethnic relations]. St. Petersburg, V. A. Mikhailov Publ. 203 p. (In Russ.).

Studenchestvo $v$ mnogonatsional' nykb megapolisakb i krupnykh gorodakb Rossii: etnicheskoe samosoznanie $i$ mezhetnicheskie otnosheniia [Students in multinational megalopolises and the large cities of Russia: Ethnic consciousness and interethnic relations] (2008) : A digest of the results of a sociological study / A. N. Pokida, N. V. Zybunovskaia, A. F. Dashdamirov, S. A. Pistriakova, S. A. Semedov, A. Yu. Soklakov and Zh. A. Shishova ; ed. by A. V. Zhuravsky. Moscow, Russian Presidential Academy of Public Administration Publ. 156 p. (In Russ.).

Ukaz Prezidenta Rossiiskoi Federatsii ot 19.12.2012 g. № 1666 «O Strategii gosudarstvennoi natsional'noi politiki Rossiiskoi Federatsii na period do 2025 goda» [President of the Russian Federation. Decree No. 1666 "On the Strategy of the State Nationality Policy of the Russian Federation until the Year 2025”, promulgated December 19, 2012]. (2012) Prezident Rossii [online] Available at: http:// kremlin.ru/acts/bank/36512 [archived in WebCite] (accessed 12.09.2015). (In Russ.).

Khairullina, N. G. and Gadzhigasanova, N. S. (2015) Proiavlenie etnicheskoi tolerantnosti v malykh sotsial'nykh gruppakh [Manifestations of ethnic tolerance in small social groups]. Sovremennye problemy nauki i obrazovaniia, no. 2 (58) [online]. Available at: http://science-education.ru/122-21309 [archived in WebCite] (accessed 12.09.2015). (In Russ.).

Shadzhe, A. Yu. (2011) Identichnost' v kontekste postneklassicheskoi nauki [Identity in the context of post-nonclassical science]. In: Identichnost' kak predmet politicheskogo analiza [Identity as a subject of political analysis]: Proceedings of the all-Russian research-to-practice conference (Institute of World Economy and International Relations, RAS, October 21-22, 2010) / ed. by I. S. Semenenko and L. A. Fadeeva. Moscow, Publ. House of the Institute of World Economy and International Relations, RAS. 299 p. Pp. 42-46. (In Russ.).

Erikson, E. H. (2006) Identichnost': iunost' i krizis [Identity: Youth and crisis]/ ed. by A. V. Tolstykh. Moscow, Flinta Publ. ; Moscow Psychological and Social Institute Publ. ; Progress Publ. 352 p. (In Russ.).

Submission date: 12.09.2015.

Гаджигасанова Наиде Сефтеровна - кандидат социологических наук, старший преподаватель кафедры социологии Ярославского государственного университета им. П. Г. Аемидова. 
Aдрес: 150000, Россия, г. Ярославль, ул. Советская, д. 10. Тел.: +7 (4852) 32-96-05. Эл. адрес: naide27@mail.ru

Хайруллина Нурсафа Гафуровна - доктор социологических наук, профессор, заведующая кафедрой социальных наук Тюменского государственного нефтегазового университета, членкорреспондент Сибирской академии наук высшей школы, академик Региональной академии менеджмента Президента Казахстана. Адрес: 625000, Россия, г. Тюмень, ул. Володарского, д. 38. Тел.: +7 (3452) 45-35-26. Эл. адрес: nur@tsogu.ru

Gadzhigasanova Naide Sefterovna, Candidate of Sociology, Senior Lecturer, Department of Sociology, P. G. Demidov Yaroslavl State University. Postal address: 10 Sovietskaya St., 150000 Yaroslavl, Russian Federation. Tel.: +7 (4852) 32-96-05. E-mail: naide27@mail.ru

Khairullina Nursafa Gafurovna, Doctor of Sociology, Professor and Chair, Department of Social Sciences, Tyumen State Oil and Gas University; Corresponding member, Siberian Academy of Higher School Sciences; Member, Regional Academy of Management of the President of Kazakhstan. Postal address: 38 Volodarsky St., 625000 Tyumen, Russian Federation. Tel.: +7 (3452) 45-35-26. E-mail: nur@tsogu.ru 